\title{
A POESIA POLÍTICA DE FERNANDO PESSOA
}

\author{
José Barreto \\ (Universidade de Lisboa)
}

\section{RESUMO}

Fernando Pessoa, conhecido sobretudo pela sua poesia lírica e prosa introspectiva, foi também, entre outras coisas, um permanente pensador e ensaísta político. Com esta faceta do escritor relaciona-se intimamente a sua produção de poesia de tema político, relativamente rara na sua obra poética e tradicionalmente olhada por estudiosos e críticos com alguma condescendência. $\mathrm{O}$ presente trabalho traça um panorama dessa poesia "menor", sobretudo satírica, relacionando-a com o contexto sociopolítico português do seu tempo e confrontando-a com as posições teóricas formuladas por Pessoa sobre literatura de motivação política.

PALAVRAS-CHAVE: Fernando Pessoa, literatura e política, poesia política, poesia satírica.

\section{ABSTRACT}

Fernando Pessoa, best known for his lyrical poetry and introspective prose, was also, among other things, a permanent political thinker and essayist. This facet of the writer is closely linked with his production of political poetry, which is relatively rare in his poetic work and traditionally viewed by scholars and critics with some condescension. This paper presents an overview of this "minor", mainly satirical poetry, relating it to the Portuguese sociopolitical context of his time and comparing it with the theoretical views held by Pessoa on politically-inspired literature.

KEYWORDS: Fernando Pessoa, literature and politics, political poetry, satirical poetry. 


\section{FERNANDO PESSOA PENSADOR E ENSAÍSTA POLÍTICO}

Atento observador e pensador político que também foi, Fernando Pessoa legou à posteridade milhares de páginas inéditas contendo apontamentos, observações, ensaios e projectos de ensaios sobre a política do seu tempo, principalmente a portuguesa, ou sobre temas mais universais de "sociologia política" (assim lhe chamava). Muito pouco do que escreveu sobre essas matérias veio a lume em sua vida. Destacam-se os dois ensaios que em 1919 publicou no jornal Acção, "Como organizar Portugal" e "A opinião pública", o panfleto de 1928 intitulado O Interregno - Defesa e Justificação da Ditadura Militar em Portugal e o artigo de grande impacto público "Associações Secretas", em defesa da Maçonaria, publicado no Diário de Lisboa em 1935. Anonimamente também publicou alguma prosa de cunho político, com especial relevo para uma entrevista inventada com um suposto refugiado antifascista italiano, uma brincadeira séria publicada em 1926 no efémero diário lisboeta Sol, que lhe permitiu expor, sob uma identidade fictícia, a sua própria opinião sobre o fascismo e Mussolini. $\mathrm{O}$ momento escolhido para essa provocação foi o da fundação em Lisboa do primeiro fascio da comunidade italiana em Portugal, com a presença de um dignitário do fascismo italiano (BARRETO, 2012a). A maior parte da prosa política de Pessoa pertence, porém, àquilo que Joel Serrão designou "vasto continente submerso", a obra impublicada ou "secreta" que a inexaurível arca conservou, incluindo projectos de publicações republicanas radicais de juventude, obras abandonadas em estado bastante avançado como History of a Dictatorship (1909-1910), bem como dezenas de ensaios, artigos, manifestos e panfletos, em boa parte deixados incompletos ou em esboço, com títulos como "The Temple of Janus", "Dissertação a favor da Alemanha na presente guerra", "O Sentido do Sidonismo", “Teoria do sufrágio político", "Cinco diálogos sobre a tirania”, "Contra a democracia”, "Introdução ao problema nacional", "Five Epistles to the Boeotians", entre muitos outros. No cruzamento do texto literário com a prosa política, deixou em estado avançado o escrito Na farmácia do Evaristo (ca. 1925), em forma de diálogos sobre a actualidade política portuguesa, travados entre os frequentadores da tertúlia de um boticário (PESSOA, 1979, p. 271-294).

Em não poucas dessas prosas políticas deixadas inéditas, embora nelas proclamasse geralmente a sua isenção e preocupação de cientificidade, Pessoa acabava por ceder a um estilo panfletário, por vezes verrinoso, como na "Carta a um herói estúpido", de 1915, em que crucificava um militar distinguido por feitos de guerra em África que estava naquele momento a ser alvo das homenagens do governo republicano e do povo de Lisboa (PESSOA, 2010a). A paixão política dominava-o por vezes totalmente, como quando escreveu uma carta infeliz ao jornal A Capital, regozijando-se pelo grave acidente sofrido em 1915 por Afonso Costa, líder do Partido Democrático. A pulsão combativa e apaixonada, frequentemente permeada de misticismo, alternava em Pessoa com a visão fria de um "raciocinador” sociológico alicerçado em vasta cultura. Embora conservasse reli- 
giosamente todos os seus papéis, incluindo os rabiscados em folhinhas de calendário ou nas costas de envelopes, é provável que, com a passagem do tempo, tenha repudiado boa parte do que neles escreveu. A incoerência das opiniões expressas, que Pessoa não considerava inconveniente e até assumia sem problema, ressalta muitas vezes dessa multidão de apontamentos. No aparente labirinto das ideias sociais e políticas de Pessoa já vários estudiosos se perderam. José Augusto Seabra (1977), não vislumbrando qualquer linha de coerência, nem sequer de evolução, no pensamento político pessoano, sustentou que ele era inclassificável, dado que as suas opiniões eram permanentemente oscilantes, contraditórias e paradoxais. Porém, ao contrário de Seabra, o próprio Pessoa enumerou vários aspectos fixos do seu pensamento: individualismo, liberalismo político e económico, nacionalismo, anticatolicismo, antissocialismo.

A crise final da Monarquia, a revolução republicana e o regime dela saído, os anos da Grande Guerra, o consulado de Sidónio Pais e o período subsequente ao seu assassinato, a agonia da Primeira República, a Ditadura Militar (1926-1933) e os começos do Estado Novo de Salazar foram as sucessivas situações políticas sobre que se debruçaram esses escritos políticos pessoanos. Em qualquer deles, mesmo durante a Ditadura Militar, que defendeu publicamente, Pessoa foi sempre um analista de perspectiva singular e olhar muito crítico - um espírito contestatário, diríamos hoje, se não optarmos pela expressão pensador marginal. Do radicalismo republicano dos 18-20 anos evoluiu para um pensamento conservador e elitista de verve antidemocrática, sem perder a sua singularidade e independência crítica. Defendeu causas perdidas e simpatizou com modelos políticos anacrónicos - como o absolutismo esclarecido de Frederico o Grande da Prússia, de quem elogiava a tolerância no plano religioso e a protecção dos artistas e da liberdade de expressão. Foi um nacionalista atípico no panorama português do seu tempo, quando por "nacionalismo" se entendia uma mescla de autoritarismo, tradicionalismo e catolicismo. Foi um defensor obstinado do individualismo, quando pela Europa de entre as duas guerras grassavam a estatolatria de direita ou de esquerda, o sindicalismo e o corporativismo. Passou ao largo do fascismo e do salazarismo, que seduziu intelectuais portugueses com um percurso semelhante ao seu. Os seus pontos de vista únicos acabavam por desagradar a gregos e a troianos, disso se queixando, por exemplo, quando publicou o citado panfleto $O$ Interregno, que considerou vítima de uma conspiração do silêncio - e que a própria Ditadura Militar, que ele ali defendia à sua peculiar maneira, só permitiu que fosse publicado com certas condições. Mais tarde, repudiou muito desse panfleto e considerou-o "não existente" (BARRETO, 2012b).

\section{A LITERATURA E A POLÍTICA, SEGUNDO PESSOA}

A poesia de tema político está presente em diferentes períodos da obra literária pessoana, mas ocupa nela um lugar secundário, dada a relativa pouca frequência com que Pessoa, um poeta essencialmente intros- 
pectivo, a cultivou. Com razão ou sem ela, essa vertente da poesia pessoana é por vezes encarada com uma espécie de benevolência condescendente, como se fosse obra menor ou mera curiosidade. Não existe testemunho de que Pessoa tivesse sobre ela opinião idêntica.

Como autor, leitor e crítico, Pessoa afirmava hostilizar por princípio a literatura de causas políticas ou sociais, ainda que também achasse que um escritor não podia abster-se de "sentir politicamente". Traía, porém, o seu "mister social" o erudito ou o escritor que se deixasse "inquinar de doutrinas políticas ou religiosas". ${ }^{1}$ Para Pessoa, os domínios da arte, da ciência e da filosofia deveriam ser ciosamente resguardados da política, da religião e da propaganda em geral, domínios a que o intelectual e o artista, membros de um escol, eram naturalmente superiores:

Um dos grandes males de que enfermam os nossos escóis literários é a introdução na literatura de fenómenos alheios a ela, como, por exemplo, a política. [...] Na literatura e na ciência, propriamente tais, a inteligência está entregue à sua própria actividade, nem deve subordinar-se a coisa alguma. Que para o teólogo a filosofia seja ancilla theologiae, está bem; não está bem que, para o filósofo, ela seja ancilar de qualquer coisa. Fazer da literatura um elemento de propaganda, seja do que for, é viciar a sua natureza e o seu fim. [...] A literatura tem também um fim moral ou social, que é ter nenhum. ${ }^{2}$

Pessoa chegou a defender que o próprio patriotismo, algo não forçosamente adstrito ao compartimento da política, deveria ser rejeitado na obra poética ou artística. Em talvez nenhum outro texto sustentou Pessoa estes pontos de vista de modo tão extremado como em "Os Fundamentos do Sensacionismo" (ca. 1915), em que proclamava o "dever" da indiferença do artista e do escritor "para com a Pátria, para com a Religião, para com as chamadas virtudes cívicas e os apetrechos mentais do instinto gregário" (PESSOA, 2009, p. 183-188). A divisão do trabalho, sem a qual não haveria perfeito funcionamento da sociedade, exigiria essa indiferença, esse distanciamento:

Todo o artista que dá à sua arte um fim extra-artístico é um infame. É, além disso, um degenerado no pior dos sentidos que a palavra não tem. É, além disso e por isso, um anti-social. A maneira de a arte ser social é ser anti-social. A maneira de o artista colaborar utilmente na vida da sociedade a que pertence é não colaborar nela. Assim lhe ordenou a Natureza que fizesse, quando o criou artista e não político ou comerciante. [...] Quanto mais instintivamente se fizer essa divisão do trabalho social, mais perfeito será o funcionamento da sociedade [...] É perfeitamente lógico que um artista pregue a Decadência na sua arte, e, se for político, pregue a Vida e Força na sua política. É, mesmo, assim que deve ser. Não se admite que um artista escreva poemas patrióticos, como não se admite que um político escreva artigos antipatrióticos. (PESSOA, 2009, p. 184-185) 
No mesmo texto, Pessoa admitia, contudo, que o psiquismo do artista não podia fechar-se à dimensão sociopolítica, por mais que dela se tentasse alhear:

Todas as questões sociais, todas as perturbações políticas, por pouco que com elas nos preocupemos, entram no nosso organismo psíquico, no ar que respiramos psiquicamente, passam para o nosso sangue espiritual, passam a ser, inquietamente, nossas como qualquer coisa que seja nossa. (PESSOA, 2009, p. 187)

Um escritor não podia abster-se rigorosamente de sentir politicamente, escrevia Pessoa numa passagem atrás citada. Por isso, continuava, o escritor devia tentar "compensar a oscilação num sentido por uma oscilação no sentido oposto". O requisito de isenção exigiria de um escritor que porventura escrevesse sobre política que apresentasse "um dia os aspectos positivos, ou negativos, de uma doutrina, no outro os aspectos positivos, ou negativos, da doutrina oposta". ${ }^{3}$ Neste texto da maturidade em que já não pregava literalmente a indiferença do escritor perante a política ou a pátria, Pessoa recusava essencialmente o espírito partidário ou sectário na literatura e na intelectualidade. "O papel da inteligência é estar au dessus de la mêlée", ${ }^{4}$ escreveu em 1934, repetindo uma frase de Romain Rolland em 1914. Outro texto seu era encimado por esta afirmação: "A função da inteligência é renegar as paixões", em La trahison des clercs, de 1927, ser o dever dos intelectuais.

Na verdade, como mais adiante se mostrará, o poeta Fernando Pessoa nunca foi exemplarmente fiel a essa compartimentação estanque da arte que em várias ocasiões defendeu, ao l'art pour l'art, à declarada repulsa pela "inquinação" política, patriótica e religiosa da literatura ou da obra de erudição. Como ensaísta, tampouco foi tão boamente imparcial que considerasse por regra os aspectos positivos e negativos de cada doutrina ou política. Na verdade, infringiu muito mais essa sua norma do que a respeitou.

\section{JUNQUEIRO E PESSOA}

A respeito da posição de Pessoa sobre a literatura politicamente motivada ou empenhada, podem proporcionar útil matéria de reflexão as apreciações encomiásticas que ele fez, desde o final da sua adolescência, da obra de Guerra Junqueiro (1850-1923). A obra junqueiriana, pelo menos a do último quartel do século XIX, é claramente marcada não só pela exaltação patriótica, como pela combatividade política e social. Junqueiro foi um poeta de tendência republicana e anticlerical (os monárquicos chamavam-lhe panfletário jacobino) cuja obra reconhecidamente contribuiu para a criação do ambiente revolucionário que conduziu à implantação da República em 1910. Foi notória a sua influência ideológica, se não a estética, sobre o jovem Pessoa, especialmente na visão que lhe transmitiu da Monarquia "decadente" e "moribunda", bem como na esperança sebastia- 
nista de uma redenção nacional. Para Junqueiro e, depois, para Pessoa, esse D. Sebastião redentor começou por chamar-se República. Para uma historiadora, Pátria de Junqueiro teria sido uma das inspirações seminais do projecto poético pessoano da Mensagem (COELHO, 1996, pp. 164 e 192), projecto, aliás, originalmente intitulado Portugal.

Guerra Junqueiro foi julgado em 1907 por ter chamado "porco" ao rei D. Carlos num jornal republicano do Porto. O jovem Pessoa, impressionado por tal acto, traduziu para inglês o texto insultuoso de Junqueiro e parte do seu depoimento de defesa em tribunal - "palavras que ficam para a história", assim as qualificou. Pessoa achava em 1909-1910 que Junqueiro era "o maior dos poetas portugueses contemporâneos" e mesmo "o maior poeta vivo da actualidade" (no mundo, presume-se). ${ }^{6}$ Apontava então $A$ Velhice do Padre Eterno como a melhor obra de Junqueiro, salientando a sua "veia anticlerical". Cinco anos depois, em 1914, ainda mantinha idênticas opiniões elogiosas, considerando, numa resposta a um inquérito do jornal República, o poema dramático Pátria superior aos Lusíadas de Camões e emparceirando a obra de Junqueiro com o Fausto de Goethe e o Prometeu Liberto de Shelley - os três cumes, para Pessoa, da "poesia superlírica moderna".

Estas apreciações sumamente elogiosas desaparecem, contudo, a partir de 1915, ano do Orpheu e das teses sensacionistas, para dar lugar a comentários depreciativos, como este: "Guerra Junqueiro? Tenho uma grande indiferença pela obra dele. Já o vi... Nunca pude admirar um poeta que me foi possível ver". ${ }^{8}$ Ou este duplo certificado de óbito, da obra e do homem, escrito depois do falecimento do poeta: "Junqueiro morreu logo que morreu". ${ }^{9}$ Em 1929, Pessoa troçaria ainda de um dos mais conhecidos poemas anticlericais de Junqueiro, "O Melro" (de 1879, incluído em A Velhice do Padre Eterno em 1885), num poema satírico que intitulou "O Anti-melro" ou "Remelro", hoje ainda largamente desconhecido. ${ }^{10}$ As duas últimas estrofes dessa sátira encenam um protesto do próprio pássaro contra Junqueiro e contra os "versos subversivos", as lições anticlericais ou políticas e os velhos "motivos de audácias". Diz o melro naturalista de Pessoa, zombando da aura republicana e anticatólica do melro de Junqueiro:

Sou um melro, e não um sócio vil

Da Associação do Registro Civil.

Sou um melro totalmente, e existo

Alheio a Cristo e a não-Cristo,

Sem dar lição alguma sobre nada,

Mera alimária alada,

Inconsciente, como o céu, de estar

Onde está, de mover-me e de cantar.

E se morri, arre!, morri.

Com isso provo que vivi.

Morri: pois deixem-me morrer

Sem me quererem compreender. 
E quanto aos versos subversivos

De Igrejas e Escrituras,

Deixem-se disso: são motivos

De audácias que já nem são bravura.

Vejam claro,

Escrevam raro,

Tenham verdade ao menos no sentir,

E então por certo me ouvirão a rir,

Madrugador, jovial,

Logo de manhã cedo

Cantando entre a verdade do arvoredo

E não entre a mentira universal. ${ }^{11}$

É talvez surpreendente que, na sua maturidade, Fernando Pessoa, enquanto crítico que fez apreciações das obras literárias de muitas dezenas de autores nacionais e estrangeiros (BOTHE, 2014), nunca tenha escrito nada sobre o empenhamento político do poeta Guerra Junqueiro, nem para o condenar, nem para o justificar. Em todo o caso, Junqueiro, que tinha combatido a Monarquia e, durante os primeiros anos da República, aceitou um cargo diplomático na Suíça, jamais pôs a pena ao serviço da política republicana, que claramente o decepcionou - embora talvez não tanto quanto a Pessoa.

\section{A POESIA POLÍTICA DE PESSOA}

Passemos em revista (não exaustiva) a poesia política de Pessoa desde o final da sua adolescência até á morte. As sátiras do jovem Pessoa assinadas pelo republicano anticlerical Joaquim Moura Costa (1909-1910), pseudónimo ou heterónimo que ficou inédito, eram poemas políticos destinados a uma quimérica publicação republicana radical, de propósitos incendiários, adequadamente chamada $O$ Fósforo e depois rebaptizada $O$ Iconoclasta, com que pretendia atacar a Monarquia dos Braganças e a sua aliada natural, a Igreja Católica. Dessa colheita, aliás não muito abundante, que inclui vários poemas obscenos e escatológicos, um dos primeiros rebentos é esta quadra epigramática não assinada, escrita por Pessoa na verdura dos seus vinte anos, em Dezembro de 1908:

É a espada, vejam bem

Que ao mal e ao crime conduz;

A espada tem uma coroa

E a coroa tem uma cruz. ${ }^{12}$

Considere-se, entre as peças mais apresentáveis de Joaquim Moura Costa, a "Origem Metafísica do Padre Matos", datada de Outubro de 1909, vituperando o director do jornal lisboeta Portugal, um diário católico muito assanhado contra os propagandistas republicanos:

O nome vão que há muito nos intruja,

O sujo Deus da humanidade suja,

Esse híper-indivíduo ora estagnado 
Para além do céu plácido e estrelado

Ora biblicamente doido e vário,

Fazendo tudo mal e ao contrário; ...

Pois bem, esta figura de destaque

Um dia (triste dia!) deu um traque.

... E o triste efeito dos divinos flatos

Caindo em terra onde mijaram gatos,

Brotou dali espontaneamente o padre Matos.

Substituindo os três versos finais por quatro novos, criou um segundo poema, com o título "Origem Metafísica do Conde de Samodães", para atacar, desta vez, o director de A Palavra, um diário católico e monárquico do Porto.

$[\ldots]$

E o sujo efeito dos divinos flatos

Caindo em chão onde mijavam gatos,

E onde haviam mijado outrora cães -

Brotou dali espontaneamente o Samodães. ${ }^{13}$

Do mesmo período (1909-1910) é esta sátira, assinada por Moura Costa e intitulada "Beija-mão", visando Veiga Beirão, chefe de um dos últimos governos da Monarquia:

Então dizem que o Beirão

Que ocupa o lugar cruel

De chefe da situação

Beijou ao Núncio o anel...

Foi para levar a cabo

Tudo a bem. Creio que diz.

Foi sinal de submissão

Pois isso foi só que não

Podia beijar-lhe o rabo

Por lho impedir o nariz. ${ }^{14}$

Com o advento da República, Moura Costa emudece e a própria poesia satírica de Pessoa desaparece por uns tempos. Os versos de cunho político regressarão após a Grande Guerra, mas num registo e género muito diferentes. A longa ode "À Memória do Presidente-Rei Sidónio Pais", publicada em 1920 no jornal Acção, ${ }^{15}$ de que Pessoa foi o principal colaborador, era um poema político, de vocação e propósito interventivos, ainda que incensando um governante já morto. A ode vestia o ancestral mito sebastianista na figura do "presidente-rei" assassinado, a quem chamava "antemanhã da Redenção". Nesse período dito pós-sidonista, a mitificação de Sidónio Pais foi cultivada por alguns escritores e publicistas, como António Ferro, que eram partidários de um presidencialismo nacionalista $\mathrm{e}$ antiparlamentar, ou seja, de uma ditadura. O "destino oculto de Portugal" começava então a interessar cada vez mais ao poeta e ensaísta Pessoa, num crescendo de misticismo e "sebastianismo racional" que o acompanharia até ao fim dos seus dias. Por altura da ode sidonista, Pessoa escreveu, na pele de um cego versejador e cantor, dúzias de quadras proféticas, à moda 
do sapateiro Bandarra. São quadras de forma tosca e mensagem política a condizer, escritas ao jeito do improviso popular, com muito pé quebrado (PESSOA, 1993, pp. 57-58 e 351-356). Ficaram então inéditas, mas eram aparentemente destinadas a agitar o povo contra a República e contra os políticos que, na Grande Guerra, tinham "vendido” os filhos de Portugal para carne de canhão.

Anda o povo a passar fome

E quem o mandou para a França

Não tem barriga para o que come

Nem mãos para o que alcança.

A salvação era apontada no regresso de uma nova versão do Encoberto, que já tinha incarnado em Sidónio.

Um dia o Sidónio torna.

Estar morto é estar a fingir.

Quem é bom pode perder a forma

Mas não perder o existir.

Em 1923, reaparece a sátira. Pessoa escreve epigramas sobre Lenine e o comunismo. O leninismo era, para ele, um misticismo político de credo sobrenaturalista:

Quem és? Lenine. Que queres? É surpresa.

Mas que surpresa queres tu fazer?

Venho alterar as leis da Natureza.

Oh, bardamerda. Não é Deus quem quer! ${ }^{16}$

O mesmo tema é abordado noutro poema (se assim se lhe pode chamar), coevo do anterior:

Quais milagres de Lourdes, meu amigo!

Milagres de Rússia.

Curar paralisias!

Curar egoísmos, isso é que é milagre.

Ah Lourdes, Lourdes, quantas Lourdes há! ${ }^{17}$

Num epigrama deste mesmo período, a democracia é definida como o regime que engendra a divisão da nação - ou, talvez, o roubo a dividir por muitos:

"Divide e reina": a antiga monarquia

Seu lema imperial assim decide.

É o contrário da democracia:

Como são muitos, é "reina... e divide." 18

Alguns anos depois, a situação política portuguesa alterou-se completamente. O golpe de 28 de Maio de 1926 fez cair o regime democrático e instaurou a Ditadura Militar. O poema satírico "Fado da Censura", escrito por Pessoa em 1927, era um ataque ao regime censório militar vigente em Portugal desde o ano anterior. Ficou inédito por motivos óbvios - as mesmas razões, talvez, por que Pessoa o não assinou. Paradoxalmente, foi escrito no mesmo ano em que redigiu O Interregno, uma "defesa e jus- 
tificação" da mesma Ditadura Militar. Defenderia porventura Pessoa uma ditadura militar ideal, sem censura? O poema, pré-intitulado "Cantiga do Bristol", do nome de um clube de diversão nocturna lisboeta pouco depois mandado encerrar pelos militares, ${ }^{19}$ obedece ao mote da quadra inicial e não consta que jamais tenha sido cantado.

\section{FADO DA CENSURA}

Neste campo da Política

Onde a Guarda nos mantém, Falo, responde a Censura;

Olho, mas não vejo bem.

Há um campo lamacento

Onde se dá bem o gado;

Mas, no ar mais elevado,

$\mathrm{Na}$ altura do pensamento,

Paira certo pó cinzento,

Um pó que se chama Crítica.

A Ideia fica raquítica

Só de sempre o respirar.

Por isso é tão mau o ar

Neste campo da Política.

Às vezes, nesta planura,

Se o vento sopra do Norte,

$\mathrm{O}$ pó torna-se mais forte,

E chama-se então Censura.

É um pó de mais grossura,

Sente-se já muito bem,

E a Ideia, batida, tem

Uma impressão de pancada,

Como a que dão numa esquadra

Onde a Guarda nos mantém.

O pó parece que chove,

Paira em todos os sentidos,

Enche bocas e ouvidos,

Já ninguém fala nem ouve.

Se a minha boca se move,

Logo à primeira abertura

A enche esta areia escura.

Só trago e me oiço tragar.

É uma conversa a calar.

Falo, responde a Censura.

Vem então qualquer vizinho,

Dos que podem abrir boca;

No braço, irado, me toca,

E diz, "Não vê o caminho?

O seu dever comezinho

De patriota aí tem. 
Vê o caminho e não vem?!"

Para isso, bolas aos molhos!

Se este pó me entrou prós olhos,

Olho, mas não vejo bem. ${ }^{20}$

Em fins de 1931, ano da instauração da Segunda República espanhola, Pessoa escreveu em verso um elogio fúnebre do falecido general Primo de Rivera (PESSOA, 1993, p. 364). O ditador espanhol deposto em 1930, morto no exílio parisiense meses depois, simbolizava para Pessoa a "alma da fidalguia da Espanha" que, com ele, teria ido a enterrar. Mas o poema também tinha uma relação com a realidade portuguesa: com a ascensão, por esses mesmos anos, de Salazar como líder político da ainda Ditadura Militar, Pessoa escreveria que "de uma simples ditadura militar à la Primo de Rivera", se tinha caído em Portugal "na actual ditadura à la Mussolini" (PESSOA, 1993, p. 370). Era um modo de atacar o mau ditador, elogiando o bom.

O livro Mensagem, premiado pela ditadura de Salazar em 1934, é uma obra poética patriótica e assumidamente nacionalista, embora imbuída de misticismo sebastianista e simbologia "fraternitária" rosicruciana, ingredientes estranhos à ideologia nacional-católica do regime então vigente, como o próprio Pessoa não deixou de sublinhar. As hesitações surgidas na atribuição do prémio pelo júri, bem como o facto de alguns apoiantes do regime considerarem Mensagem um poema derrotista, provam que o galardão se deveu principalmente à aposta pessoal e insistente de António Ferro no poeta, a quem, segundo afirmou, desejava promover, retirando-o do seu isolamento. Adiante voltaremos a Ferro e à sua aposta em Pessoa.

Enfim, as sátiras contra Salazar e o Estado Novo escritas em 1935 eram poemas vocacionados para o combate político - que Pessoa entendia como um combate exclusivamente individual, além de forçosamente anónimo e clandestino, nas circunstâncias do regime autoritário e censório. Nelas reaparece, com uma verve geralmente menos incendiária e uma ironia mais subtil, o Joaquim Moura Costa da juventude. É bem conhecido o tríptico satírico sobre o "tiraninho" António de Oliveira Salazar, composto em Março-Abril de 1935, publicado pela primeira vez por Jorge de Sena no jornal O Estado de S. Paulo, em 1960, e só muito depois em Portugal, após a revolução de Abril de 1974. ${ }^{21}$ Cópias dactilografadas dos três poemas (inicialmente, apenas dos dois primeiros) tinham circulado anonimamente pelos cafés em 1935, assinadas por "Um sonhador nostálgico do abatimento e da decadência" - referência de Pessoa a uma frase de um discurso de Salazar em Fevereiro desse ano, defendendo a censura e a imposição de directrizes políticas aos escritores e artistas. Eis o triplo poema:

António de Oliveira Salazar.

Três nomes em sequência regular...

António é António.

Oliveira é uma árvore.

Salazar é só apelido. 
Até aí está bem.

O que não faz sentido é o sentido que isto tem.

Este senhor Salazar

É feito de sal e azar.

Se um dia chove,

A água dissolve

O sal,

E sob o céu

Fica só o azar, é natural.

Oh, c'os diabos!

Parece que já choveu...

\section{Coitadinho}

Do tiraninho!

Não bebe vinho,

Nem sequer sozinho...

Bebe a verdade

E a liberdade,

E com tal agrado

Que já começam

A escassear no mercado.

Coitadinho

Do tiraninho!

O meu vizinho

Está na Guiné,

E o meu padrinho

No Limoeiro

Aqui ao pé,

Mas ninguém sabe porquê.

Mas, enfim, é

Certo e certeiro

Que isto consola

E nos dá fé:

Que o coitadinho

Do tiraninho

Não bebe vinho,

Nem até

Café. ${ }^{22}$

Do início da fornada satírica de 1935 é também o conhecido poema "Liberdade", cortado pela censura na Seara Nova, mas deixado passar na mesma revista dois anos após a morte do autor. Sabemos hoje tratar-se 
de um remoque ao mesmo discurso de Salazar, pleno de ironia sibilina (PRISTA, 2003).

LIBERDADE

(falta uma citação de Séneca ${ }^{23}$ )

Ai que prazer

Não cumprir um dever,

Ter um livro para ler

E não o fazer!

Ler é maçada,

Estudar é nada.

O sol doura

Sem literatura.

O rio corre, bem ou mal,

Sem edição original.

E a brisa, essa,

De tão naturalmente matinal,

Como tem tempo não tem pressa.

Livros são papéis pintados com tinta.

Estudar é uma coisa em que está indistinta

A distinção entre nada e coisa nenhuma.

Quanto é melhor, quando há bruma,

Esperar por D. Sebastião,

Quer venha ou não!

Grande é a poesia, a bondade e as danças...

Mas o melhor do mundo são crianças,

Flores, música, o luar, e o sol, que peca

Só quando, em vez de criar, seca.

$\mathrm{O}$ mais do que isto

É Jesus Cristo,

Que não sabia nada de finanças

Nem consta que tivesse biblioteca...

Em Abril de 1935, após a aprovação pela Assembleia Nacional estadonovista do projecto de lei contra a Maçonaria, o tom dos poemas políticos pessoanos torna-se mais carregado. É o caso deste, sem título:

Solenemente

Carneirissimamente

Foi aprovado

Por toda a gente

Que é, um a um, animal,

$\mathrm{Na}$ assembleia nacional

Em projecto do José Cabral.

Está claro

Que isso tudo 
É desse pulha austero e raro

Que, em virtude de muito estudo,

$\mathrm{E}$ de outras feias coisas mais

É hoje presidente do conselho,

Chefe de infernanças animais,

E astro de um estado novo muito velho.

Que quadra

Isso com qualquer coisa que se faça?

Nada.

A Igreja de Roma ladra

E a Maçonaria passa.

E eles todos a pensar

$\mathrm{Na}$ vitória que os uniu

Neste nada que se viu,

Dizem, lá se conseguiu,

Para onde agora avançar?

Olhem, vão p'ra o Salazar

Que é a puta que os pariu. ${ }^{24}$

No verão de 1935 foi inaugurada a rádio oficial do regime, a Emissora Nacional, vocacionada para transmitir em permanência a propaganda salazarista. Pessoa dedicou-lhe este poema irritado:

À Emissora Nacional

Para a gente se entreter

E não haver mais chatice

Queiram dar-nos o prazer

De umas vezes nos dizer

O que Salazar não disse.

Transmitem a toda a hora,

Nas entrelinhas das danças,

"Salazar disse" (Emissora)

E aí vem essa senhora

A Estada Nova com tranças.

Sim, talvez seja o melhor,

Porque estes homens de estado

Quando falam, é o pior,

E então quando são do teor

Do chatazar já citado! ${ }^{25}$

Nesse verão, entre vários outros poemetos satíricos contrários ao regime de Salazar, Pessoa compôs um poema mais longo, sem título, passando em revista os principais temas da propaganda do Estado Novo e submetendo-os a uma crítica sarcástica. 
Sim, é o Estado Novo, e o povo

Ouviu, leu e assentiu.

Sim, isto é um Estado Novo,

Pois é um estado de coisas

Que nunca antes se viu.

Em tudo paira a alegria,

E, de tão íntima que é,

Como Deus na teologia

Ela existe em toda a parte

E em parte alguma se vê.

Há estradas, e a grande Estrada

Que a tradição ao porvir

Liga, branca e orçamentada,

E vai de onde ninguém parte

Para onde ninguém quere ir.

Há portos, e o porto-maca

Onde vem doente o cais.

Sim, mas nunca ali atraca

O paquete Portugal

Pois tem calado de mais.

Há esquadra... Só um tolo o cala, Que a inteligência, propícia

A achar, sabe que, se fala,

Desde logo encontra a esquadra:

É uma esquadra de polícia.

Visão grande! Ódio à minúscula!

Nem para prová-la tal

Tem alguém que ficar triste:

União Nacional existe,

Mas não união nacional.

E o Império? Vasto caminho

Onde os que o poder despeja

Conduzirão com carinho

A civilização cristã,

Que ninguém sabe o que seja.

Com "directrizes" à arte

Reata-se a tradição,

E juntam-se Apolo e Marte

No Teatro Nacional,

Que é onde era a Inquisição.

E a fé dos nossos maiores?

Forma-a, impoluta, o consórcio

Entre os padres e os doutores. 
Casados o Erro e a Fraude ${ }^{26}$,

Já não pode haver divórcio.

Que a fé seja sempre viva,

Porque a esperança não é vã!

A fome corporativa

É derrotismo. Alegria!

Hoje o almoço é amanhã. ${ }^{27}$

Pessoa retomaria um modelo semelhante a esse em Novembro, mês da sua morte, para escrever o "Poema de Amor em Estado Novo", um dos mais trabalhados e bem conseguidos. Trata-se de uma extraordinária troça das referidas directrizes salazarianas destinadas aos escritores e artistas, a que o poeta finge obedecer, dedicando um longo e ridículo discurso amoroso a todos os temas e slogans da propaganda do regime. A forma adoptada justificava-se pelo facto de a tradicional poesia amorosa ser considerada pela censura como politicamente inofensiva. Para cúmulo da provocação, o poema é assinado por "O demo-liberalismo maçónico-comunista" - outro chavão do discurso do regime, que metia todos os seus adversários no mesmo saco.

Poema de Amor em Estado Novo

Tens o olhar misterioso

Com um jeito nevoento,

Indeciso, duvidoso,

Minha Maria Francisca,

Meu amor, meu orçamento!

A tua face de rosa

Tem o colorido esquivo

De uma nota oficiosa.

Quem dera ter-te em meus braços,

Ó meu saldo positivo!

E o teu cabelo - não choro

Seu regresso ao natural -

Abandona o estalão-ouro,

Amor, pomba, estrada, porto,

Sindicato nacional!

Não sei porque me desprezas.

Fita-me mais um instante,

Lindo corte nas despesas,

Adorada abolição

Da divida flutuante!

Com que madrigais mostrar-te

Este amor que é chama viva?

Ouve, escuta: vou chamar-te

Assembleia Nacional,

Câmara Corporativa. 
Como te amo, como, como,

Meu Acto Colonial!

De amor já quase não como,

Meu Estatuto do Trabalho,

Meu Banco de Portugal!

Meu crédito no estrangeiro!

Meu encaixe-oiro adorado!

Serei sempre o teu romeiro...

Pousa a cabeça em meu ombro,

Ó meu Conselho de Estado!

Ó minha corporativa,

Minha lei de Estado Novo,

Não me sejas mais esquiva!

Meu coração quer guarida

Ó linda Casa do Povo!

União Nacional querida,

Teus olhos enchem de mágoa

A sombra da minha vida

Que passa como uma esquadra

Sobre a energia da água.

Que aristocrático ri

O teu cabelo em cifrões -

Finanças em mise-en-plis!

Meu altivo plebiscito,

Nunca desceste a eleições!

Por isso nunca me escolhes

E a minha esperança é vã.

Nem sequer por dó me acolhes,

Minha imperialmente linda

Civilização cristã!

Bem sei, por estes meus modos

Nunca me podes amar.

Olha, desculpa-mos todos.

Estou seguindo as directrizes

Do Professor Salazar. ${ }^{28}$

\section{CONCLUSÃO}

Pode discutir-se se, nas poesias politicamente empenhadas atrás enumeradas, Pessoa traiu ou não as suas teses sensacionistas de 1915, que rejeitavam liminarmente a literatura de motivação ou fim político - teses, aliás, por ele reiteradas em datas posteriores, ainda que de forma muito mais ponderada. De facto, não parece ter-lhes sido fiel, mas talvez Pessoa não considerasse esses poemas como verdadeira poesia ou a sua poesia. Em todo o caso, algo que o poeta nunca renegou foi a atitude de insubmissão 
intelectual aos poderes constituídos, de insubordinação aos cânones mentais e estéticos, de inconformismo e não-colaboracionismo com o status quo - uma atitude evidente e constante tanto na sua obra literária como na ensaística. Assim, talvez se devesse interpretar de preferência as teses de 1915 como a proclamação por Pessoa de uma marginalidade elitista contra aquele "instinto gregário" a que ele foi sempre refractário - isto é, mais como uma afirmação de desprezo pelos padrões políticos, mentais e religiosos dominantes do que como um elogio literal da indiferença ou do alheamento do escol perante a problemática política ou religiosa. $\mathrm{O}$ ano de 1915 tinha sido, a vários títulos, um momento de viragem para Pessoa. Após a revolução sangrenta de 14 de Maio desse ano, que recolocou o Partido Democrático no poder, operou-se uma reviravolta na sua mente, começando a encarar a República como um regime ainda mais nefasto do que a Monarquia decadente derrubada em 1910. As teses sensacionistas enquadram-se em parte nessa evolução e nesse novo "sentir político".

Se, como poeta, Pessoa recusou sempre servir uma propaganda ou incensar o poder (nunca elogiou publicamente um governante, nem o fez, sequer, enquanto Sidónio Pais foi vivo), não resistiu porém, se bem que só esporadicamente, a expressar o seu sentir político e a fazer a propaganda das suas próprias ideias através do verso, mas sempre em antagonismo ou, pelo menos, divergência com o poder vigente. As sátiras políticas de 19091910, 1923, 1927 e 1935 visavam a ordem estabelecida - a aliança do trono e do altar no primeiro caso, a instabilidade da democracia no segundo, a instituição da censura no terceiro, Salazar e o salazarismo no último. A ode à memória do "Presidente-Rei" Sidónio Pais era um "poema monárquico", (como a rotulou o próprio jornal que a publicou), claramente dirigido contra a República então vigente - como o foram também as quadras do cego bandarrista e, ainda, certos poemas verrinosos escritos para a gaveta, em defesa da restauração monárquica ou contra o líder republicano Afonso Costa, apodado de traidor à pátria (PESSOA, 1993, pp. 349-351).

O caso do livro Mensagem (publicado em 1934, mas escrito ao longo de duas décadas) será porventura menos evidente como exemplo dessa atitude de marginalidade e não-colaboracionismo com o poder, não propriamente pelo seu conteúdo - embora sobre ele se tenham feito especulações completamente infundadas ${ }^{29}$-, mas pela tentativa de instrumentalização de que a obra foi realmente alvo por parte do poder, na pessoa do director da propaganda do Estado Novo, o já referido António Ferro. Diga-se que a tentativa de recrutamento político do poeta pela via do prémio literário e de cooptação da sua obra "nacionalista" e "profética" para fins de propaganda do regime surtiu um efeito contrário ao desejado. Quando o escritor premiado, repelindo a transparente tentativa de captação, exibiu a breve trecho a sua independência política através de uma afrontosa defesa pública da Maçonaria, então o principal inimigo do regime, logo a obra Mensagem serviu ao órgão oficial do governo para o trocadilho chocarreiro maçagem, com o intuito de desqualificar a intervenção do ingrato escritor, acrescentando um desabafo significativo: "Vá lá a gente fiar-se em poetas!" 30 Pessoa, por seu lado, comentaria o episódio com incontida satisfação: "Pela primeira vez na minha vida fabriquei uma bomba" (PESSOA, 
2011, p. 92). Contudo, impedido pela censura de responder aos críticos do seu artigo-bomba, o escritor acabou por se refugiar numa atitude de pessimismo e resignação. Nos meses anteriores à sua morte, escreveu uma longa "Elegia na sombra" para desdizer e revogar o optimismo do grito "É a hora!" de Mensagem e, pouco depois, este rubayat em que preconizava abdicação silenciosa e obediência resignada ao poder, fosse ele bom ou mau:

Ouvi os sábios todos discutir.

Podia a todos refutar a rir.

Mas preferi, bebendo na ampla sombra,

Indefinidamente só ouvir.

Manda quem manda porque manda, nem Importa que mal mande ou mande bem.

Todos são grandes quando a hora é sua.

Por baixo cada um é o mesmo alguém.

Não invejes a pompa, e ao poder,

Visto que pode, sem razão nem ser

Obedece, que a vida dura pouco.

Nem há por isso muito que sofrer. ${ }^{31}$

\section{REFERÊNCIAS BIBLIOGRÁFICAS}

BARRETO, José. Mussolini é um louco: uma entrevista desconhecida de Fernando Pessoa com um antifascista italiano. Pessoa Plural, n. 1, 2012a, pp. 225-252.

. A publicação de O Interregno no contexto político de 19271928. Pessoa Plural, n. 2, 2012b, pp. 174-207.

BOTHE, Pauly Ellen. Apreciações Literárias de Fernando Pessoa. Lisboa: INCM, 2014.

COELHO, M. Teresa Pinto. Apocalipse e Regeneração: O Ultimatum e a Mitologia da Pátria na Literatura Finissecular. Lisboa: Cosmos, 1996.

CUNHA, Teresa Sobral; SOUSA, João Rui de. Fernando Pessoa: o último ano. Lisboa: Biblioteca Nacional, 1985.

MARGARIDO, Alfredo. Introdução a Fernando Pessoa, Santo António, São João, São Pedro. Lisboa: A Regra do Jogo, 1986, p. 9-90.

Pessoa: na 'situação' ou na 'oposição'? JL - Jornal de Letras, Artes e Ideias, Lisboa, n. 177, 26 de Novembro de 1985, p. 17.

PESSOA, Fernando. Associações Secretas e Outros Escritos. Ed. José Barreto. Lisboa: Ática, 2011.

. Carta a um herói estúpido. Ed. Jerónimo Pizarro. Lisboa: Ática, 2010a.

Da República. Organização de Joel Serrão. Lisboa: Ática, 1979. 
. Livro do Desasocego. Ed. Jerónimo Pizarro. Lisboa: INCM, 2010b.

. Pessoa Inédito. Organização Teresa Rita Lopes. Lisboa: Livros Horizonte, 1993.

Estampa, 1990.

Pessoa por Conhecer, t. II. Org. Teresa Rita Lopes. Lisboa:

. Poemas de Fernando Pessoa 1921-1930. Ed. Ivo Castro. Lisboa: INCM, 2001.

. Poemas de Fernando Pessoa 1934-1935. Ed. Luís Prista. Lisboa: INCM, 2000.

Poesia 1931-1935 e não datada. Eds. M. Parreira da Silva e Ana M. Freitas. Lisboa: Assírio \& Alvim, 2006.

INCM, 2009.

. Sensacionismo e outros ismos. Ed. Jerónimo Pizarro. Lisboa:

Sobre o Fascismo, a Ditadura Militar e Salazar. Ed. José Barreto. Lisboa: Tinta da China, 2015.

PRISTA, Luís. O melhor do mundo não são as crianças. In VVAA, Razões e Emoção: Miscelânea de Estudos em Homenagem a Maria Helena Mira Mateus. Lisboa: INCM, 2003, pp. 217-238.

SEABRA, José Augusto. Poética e política em Fernando Pessoa. Persona, Porto, n. 1, 1977, pp. 11-20.

Recebido para publicação em 30/11/14

Aprovado em 22/01/15

\section{NOTAS}

1 "A inteligência pode empregar-se em três fins superiores..." (BNP/E3, 92A-7 $)$, texto aparentemente datável do início dos anos 1930.

2 "Um dos grandes males de que enfermam os nossos escóis literários..." (BNP/E3, 100$33^{\text {r }}$ ), texto aparentemente datável do início dos anos 1930 .

3 "A inteligência pode empregar-se em três fins superiores...", cit.

4 "A inteligência e a política", BNP/E3, 92-27r

5 “A função da inteligência é renegar as paixões...” BNP/E3, 92E-3.

$6 \mathrm{BNP} / \mathrm{E} 3,14 \mathrm{C}-30^{\mathrm{r}}$ a $35^{\mathrm{r}}$. Inédito.

7 Resposta ao inquérito "O mais belo livro dos últimos trinta anos", in República, 7 de Abril de 1914.

8 Comentário manuscrito de ca. 1915, publicado em Pessoa, 2010b, p. 680.

9 Texto pós-1923. Publicado em Bothe, 2014, p. 286.

10 “O Anti-melro" foi publicado pela primeira vez na edição crítica da obra poética (Pessoa, 2001:151).

$11 \mathrm{BNP} / \mathrm{E} 3,60-39^{\mathrm{r}}$ a $41^{\mathrm{r}}$. Esta fala do melro está no poema entre aspas. 
12 BNP/E3, 56-8 . Publicado pela primeira vez em Pessoa, 1993, p. 340.

$13 \mathrm{BNP} / \mathrm{E} 3,56-36^{\mathrm{r}}$ e $37^{\mathrm{r}}$ (as duas versões do poema, não consideradas como tais em Pessoa, 1990, p. 219).

14 BNP/E3, 66C-28 . Publicado pela primeira vez, com erros fatais de leitura, em Pessoa, 1990, pp. 219-220.

15 O poema foi publicado no jornal Acção sob o título "À Memória do Presidente Sidónio Pais". O novo título, com a expressão "Presidente-Rei”, destinava-se a uma reedição que não ocorreu em vida do autor.

16 BNP/E3, 59-38 ${ }^{\text {r }}$ Publicado pela primeira vez em Pessoa, 2001, p. 293.

17 BNP/E3, 59-37r. Publicado pela primeira em Pessoa, 2001, p. 59.

18 BNP/E3, 59-41' . Publicado pela primeira em Pessoa, 2001, p. 61.

19 Manuela Parreira da Silva observa, com pertinência, que a alusão ao "Bristol" pode estar relacionada com a frustrada revolta armada contra a ditadura de 7 de Fevereiro de 1927, cujo comando estava instalado no Hotel Bristol, em Lisboa (Pessoa, 2006, p. 586).

20 BNP/E3, 46-26r. Publicado pela primeira vez em Pessoa, 2006, pp. 470-471.

21 A série de sátiras políticas pessoanas de 1935 só muito gradualmente se foi tornando conhecida do público, desde as revelações de Jorge de Sena nas décadas de 1960-1970 até à publicação dos últimos inéditos nas primeiras décadas do presente século (ver Pessoa, 2015).

$22 \mathrm{BNP} / \mathrm{E} 3,92 \mathrm{U}-32^{\mathrm{r}}$. Trata-se de um dactiloscrito do espólio do poeta em que aparecem reunidos os três poemas, sem título.

23 Assim no original e assim mesmo publicado em Setembro de 1937 na Seara Nova. A frase de Séneca a que o autor se referia, "Em estantes altas até ao tecto, adornam o aposento do preguiçoso todos os arrazoados e crónicas”, tinha sido citada por Salazar no referido discurso de 21 de Fevereiro, pretendendo com isso justificar a censura e a imposição de “directrizes" à arte e à literatura.

24 Publicado pela primeira vez em Pessoa, 2000, p. 199. José Cabral foi o deputado autor do projecto de lei de extinção da Maçonaria.

25 Publicado pela primeira vez em Pessoa, 2000, p. 198. No original manuscrito, chatazar é variante de Salazar.

26 Variante: Asneira.

27 BNP/E3, 92U-30. Publicado pela primeira vez por Jorge de Sena no Diário Popular de 30 de Maio de 1974.

$28 \mathrm{BNP} / \mathrm{E} 3,63-51^{\mathrm{r}}$ a 53 ${ }^{\mathrm{r}}$. Publicado pela primeira vez, com diferenças, em Cunha e Sousa, 1985, pp. 134-139.

29 Alfredo Margarido sustentou que Mensagem representava uma colaboração de Pessoa com a estética do salazarismo (MARGARIDO, 1986, p. 12). O mesmo autor taxara já de forma escandalosamente inepta o livro Mensagem como uma "obra de exaltação nacional-fascista" (Margarido, 1985).

30 “Um poeta e o papão (e que papão!) maçónico", in Diário da Manhã, 5 de Fevereiro de 1935, p. 1. Ver também o posfácio a Pessoa, 2011, pp. 253-254.

$31 \mathrm{BNP} / \mathrm{E} 3,63-43^{\mathrm{r}}$. Publicado pela primeira vez em Eduardo Lourenço e A. Braz de Oliveira (eds.), Fernando Pessoa no seu Tempo, Lisboa, Biblioteca Nacional, 1985, p. 122. 